\title{
THE METHODOLOGY OF PSYCHOLOGICAL RESEARCH OF ECOLOGICAL CONSCIOUSNESS
}

\author{
Irina A. Shmeleva \\ Saint Petersburg State University \\ Saint Petersburg
}

The paper examines the methodological principles of the psychological study of ecological consciousness as one of the urgent interdisciplinary problems of XX-XXI century, caused by the aggravation of global ecological problems and the need for the realization of the "sustainable development"ideas. Ecological consciousness is considered as multilayered, dynamic, reflexive element of human consciousness, incorporating multivariate, holistic aspects of interaction of the human being as the H.S. and the Humanity representative with the environment and the Planet. The possibility of the more active introduction of Russian psychology in the process is argued for in connection with the existing conceptual approaches, which compose the methodological basis for ecological consciousness research. Among these approaches are considered: the principles of holistic study of the human being by B. Ananyev, the methodology of system psychological description by V. Gansen and G. Sukhodolsky, the idea of reflexivity of consciousness by S. Rubinstein, the humanitarian- ecological imperative of the development of consciousness by V. Zinchenko, the theory of relations by V. Myasishev, consideration of ecological consciousness as relation to nature by $\mathrm{S}$. Deryabo and V. Yasvin, theories of consciousness by V. Petrenko, V. Allakhverdov and other Russian psychologists. The value component of ecological consciousness is distinguished as the most significant. The possibility of applying the Values' theory of the by S. Schwartz for studying the ecological values is discussed along with the prognostic potential of the universalism value.

Keywords: Ecological consciousness, sustainable development, holistic study of human being, system psychological description of consciousness, reflection, values, ecological values, universalism

Ecological consciousness (EC) has become a focus of interdisciplinary research in philosophy and sociology, as well as in various branches of psychology. For the past 20 years, from 1985 to 2006, interest in this field has grown apace. This may be explained by the fact that the problem of the survival of the human race has moved to the forefront 
of international discourses in the natural sciences, social science and the humanities, and political science. Recent years in international and Russian psychology have seen a revival of interest in the problems of the interaction of man and society with nature, the biosphere, and the environment. This interest is directly related to the intensification of global environmental problems represented by climate change, loss of biodiversity, destruction of forests, freshwater shortages, solid waste management problems, natural resource depletion, poverty and illness, and the increase in natural disasters, as outlined in the UN report "Global Environmental Outlook - 2000".

The problem of the survival of humanity on a global scale has come to occupy a central place as our planet becomes more and more interconnected politically, economically, and socially, and as the security, health and well-being of every human being is more and more dependent on the ecological well-being of the planet as a whole. The need to carry out research and practical steps related to worldwide social and psychological promotion of the concept of sustainable development, adopted in 1987 by the UN, has also contributed to this shift in priorities. In that document, sustainable development was defined as "development that meets the needs of the present generation without compromising the ability of future generations to meet their own needs." At present, globalization and sustainable development are two of the concepts dominating discussions that focus on present and future social transformation, including those of a new field of research: the psychology of sustainable development.

It is generally accepted that the ecological crisis is a result of deformations of the ecological consciousness of the inhabitants of planet Earth. These deformations are revealed at different levels of the interaction of human beings with their environment, and become apparent in decision-making regarding environmental problems in industry, economics, education, health care, and politics. This point of view was reflected in a range of initiatives undertaken by the international community: in common documents and declarations-the Earth Charter, activities of the Club of Rome and the UN International Human Dimensions Programme (IHDP); in environmental policy at the local and regional levels; and in the ideas of global environmental governance. It should be stressed that the international scientific community recognized the need to apply psychological knowledge and skills to the task of solving environmental problems over fifteen years ago. The IHDP programme was initiated by European psychologists who obtained very significant results in their initial research projects demonstrating psychological thresholds and barriers in perceiving global environmental changes.

The situation in Russia is considerably different from that of the developed European countries. It is exacerbated by the protracted economic transition, profound changes in value orientations in individual consciousness, and social apprehensions, all of them intensified by the economic crisis, which could seriously jeopardize opportunities for solving environmental problems. One of the main characteristics of Russian environmental politics is the sharp difference between what is publicly declared and the measures that are actually carried out. Examples of this are the Ecological Doctrine, announced in 2002 but still not implemented; violations of the rights of Russian citizens to a safe environment and to objective and reliable information on the real environmental state of affairs, for instance in large industrial cities; destruction of traditional environmental management systems of the indigenous peoples of Russia; and other issues. Some positive changes, and a slight increase in the frequency of discussion about the global environmental problems, occurred after 2008; but the situation remains fraught and uncertain.

The role of Russian psychology and other social disciplines in the environmental policy of Russia is negligible and insufficiently defined. This is another reminder of the urgency of research on ecological consciousness. It should be mentioned that V.P Zinchenko highlighted the importance of the humanitarian-ecological imperative as early as 1991, when he articulated the need to develop an ecological and humanitarian consciousness aimed at seeking out paths for the survival of humanity and for the prevention of an approaching anthropogenic catastrophe.

The analysis of ecological consciousness as a problem of psychological research presumes a range of interrelated issues and tasks, which could include:

- Definition of "ecological consciousness" and its phenomenological description;

- Description of the space of the existence of the ecological consciousness;

- Definition of relations between "consciousness-ecological consciousness-activity," "ecological consciousness-worldview," and so on; 
- Placing the problem of ecological consciousness in the structure of psychological science and revealing interdisciplinary links;

- Systemic psychological description of ecological consciousness and creation of its conceptual model;

- Empirical study of individual structural and functional components of ecological consciousness, and the degree of manifestation and development of ecological consciousness as a whole;

- Identification of individuals with highly developed ecological consciousness, and psychological examination of these individuals;

- Identification of relationships between the level of development of ecological consciousness and pro- and anti- ecological behaviour, environmental activities.

- Investigation of the patterns and conditions for development of ecological consciousness.

According to V.F. Petrenko and O.V. Mitina (1997), the multidimensionality of consciousness determines and defines the multidimensionality of paths of development of society, thus leading many authors to distinguish among forms of consciousness, such as: a) religious; b) ethical; c) aesthetic; d) legal; e) political; f) professional; g) ecological.

At the same time, in light of the words of S.L. Rubinshtein (1976), who claimed that "with the coming into existence of the human being, the Universe becomes a consciously comprehended Universe that is changed by the actions of human beings in it [...] consciousness and activity become new forms of existence in the Universe itself, and not the subjectivity of [a] consciousness which remains foreign to it," one might ask whether ecological consciousness is the most developed form of consciousness per se, since integrated wholeness is the cornerstone of ecological consciousness, and reflection on the global problem of human survival its key element. There is a theory that primitive consciousness in the Paleolithic age may be characterised by primitive syncretism: the non-individuation in consciousness and conscious activity of various principles-rational, irrational and aesthetic-coloured by deep emotional experience. The main feature of consciousness at that period is considered to be holism and unity, in which the supernatural and natural, the seen and the unseen, were equally real.

Ecological consciousness in the era of globalization, having undergone a long evolution, acquires the qualities and elements of reflective, visionary, noospheric consciousness, of collective intellect (according to (Moiseev, 2000)), and reinstates integrity and wholeness as a primary characteristic.

A methodological platform for the contemporary analysis of ecological consciousness might be:

- Principles of holistic study of the human being

- Paradigm of the noosphere;

- Principles of systemic psychological description of consciousness as a psychic phenomenon;

- Accumulated psychological knowledge of consciousness.

According to the concept of the comprehensive study of the human being by B.G. Ananyev (1980), the general structure of the human being and interrelationships among his traits comprises such levels as "Human being as representative of the species Homo Sapiens," and "Humanity as the history of society," with evident connections to the cosmos and Noosphere, phylogenesis, and the history of development of civilizations. B.G. Ananyev stated that the "individuality of the human being can be understood only by taking the whole set of characteristics of the human being into account, as part of the species Homo Sapiens and representative of Humanity, which forms the basis for any definition of the condition of individual human beings". This corresponds to the V.I Vernadsky's notion (2002) that "a human being, like all living things, is not a self-sufficient natural object independent of the environment. Human beings and humanity are connected, first and foremost, with the living matter that populates our planet, from which they truly cannot be separated by any physical process... The biosphere...is transformed into a new evolutionary state -the noosphere, and is elaborated and processed by the scientific thought of social humanity".

The paradigm of the noosphere has not been a priority in Russian psychology, despite the existence of fundamental premises for it in the natural and social sciences, the humanities, and philosophy, as articulated in the ideas of Teilhard de Chardin, Ch. Leroy, V.I. Vernadsky, A.L. Tchizhevsky, L.N. Gumilev, K.N. Tziolkovksy, N.N. Moiseev, I.M. Zabelin, B.G. Ananyev.

As in the rest of the world, the beginning of the 21st century in Russian psychology witnessed a publication boom on the problems of consciousness (Allakhverdov, 2000; Ulybina, 2001; Akopov, 2002; Raikov, 2002; Agafonov, 2003; Petrenko 2005; Deryabo, 1999, etc). The authors 
approach the study of consciousness from different positions, the general ideas of which provide us with a theoretical scheme for the study and analysis of consciousness in general, and ecological consciousness in particular. Meta-analysis of the different studies of consciousness and its systemic description provide an opportunity for building a systemic foundation for the study of ecological consciousness as one of its forms. Rather than repeating the well-known principles and notions of the systems approach and systems analysis, we will point to the surprising fact, noted by Agafonov (2003), that as early as 1896, W. Wundt, defining the three paramount research goals for psychological science, in effect used the principles of systems research of cognition. He defined the goals as follows:

- Description of the elementary components of consciousness

- Defining the character of the links between the elements of consciousness (establishing the means of organisation of elements in the structure of immediate experience);

- Defining the principles according to which these means of organisation are manifested; in other words, disclosure of the mechanisms that provide the connections among elements.

In modern psychology, systemic psychological description is defined as a form of presentation of information on the systemic organisation of a complex object, reflecting the content, structure, function, and other systemic traits. Different forms of coding, languages, and forms of presentation of information are used to construct it. Systemic description allows one to systematise accumulated knowledge, overcome its redundancy or reveal its insufficiency, find invariants, and formulate new scientific hypotheses. At the same time, it should be appropriate and adequate for the object under study, it should not contradict the main body of knowledge accumulated in this science, it should be open for inclusion of new data, and it should allow for further development (Ganzen, 1984). The methodology of systemic psychological description was developed by the St. Petersburg psychological school (B.G. Ananyev, V.A. Ganzen, G.V. Suchodolsky) and has been repeatedly applied in the task of representing various psychic phenomena.

A systemic psychological description of conscience could comprise the following elements:

a) morphology: content and the structure of the phenomenon manifested in structure and organization; b) axiology: the system of needs and values related to a psychic phenomenon under consideration,

c) functioning: development and functions of the phenomenon under consideration;

d) ontology: peculiarities of existence of different forms and components, characteristics, understanding of a given phenomenon in theoretical and practical models;

e) praxsiology: as a direct link with human activity and behaviour.

At the same time, we share the views of G.V. Sukhodolski (1998) and V.M. Allakhverdov (2000), which suggest that no single way of describing reality is full and comprehensive. As a rule, one accepts the completeness possible at a given stage, and sufficient for practical and theoretical purposes. In any science the languages of description intertwine; but such intertwining is particularly strong in psychology. The researcher always faces the question of the adequacy and sufficiency of the chosen dimensions of analysis. We can assume that every critical researcher understands the limits of his or her own capacity to reach the ideal.

For the purposes of our analysis, the basis for the methodology of systemic descriptions are the principles of multiplicity of descriptions, the construction of the "systemic foundation," which reveals the necessary and sufficient aspects of depictions (descriptions) of the systemic object under study (Ganzen, 1984). We believe that the conceptual model of any psychic phenomenon, built according to the principles of systemic description, can be a form of the "Mendeleev table", highlighting "white" and "dark" spots of the space of knowledge of the phenomenon under study. For example, in the case of the study of activity and development there are fewer "white spots" than in the case of study of consciousness in general, and ecological consciousness in particular.

S.L. Rubinshtein (1996) assumed that the integral qualitative characteristic of consciousness is a capacity of the subject to surpass the limits of its own existence and comprehend its relation to the wider world, and to bear responsibility for its actions; i.e., in fact he meant reflexivity of consciousness. As noted by V.P. Zinchenko (1991), reflexive consciousness is a certain level of cognitive abstraction allowing a human being to determine values, beliefs and convictions, goals and strategies. It is reflexivity that gives a human being new understanding in life. Due to reflexivity, consciousness finds, misleads, loses, creates, and works intensively. Tragedy occurs, according to him, when consciousness be- 
lieves itself to be free of natural and cultural history, breaks free of responsibility, and aspires to play the role of Demiurge.

At the end of the 20th century, according to F. Capra, cognitive science, as a wide interdisciplinary field of research and a priority of research in psychology, developed the notions of two types of cognition. The first could be called elementary; the second, reflexive, including the selfconsciousness of the thinking and reflecting subject. It is reflexivity that gives a human being a new understanding of life (Capra, 2002). These ideas correspond to the theoretical concepts developed by the Russian psychologists L.S. Vygotsky, S.L. Rubinstein, A.N. Leontiev, and others.

Summarizing and abstracting from the multi-faceted research of consciousness, and using the results of meta-analysis (Zinchenko, and Morgunov, 1994; Akopov 2002; Agafonov, 2003), we are able to identify components that could be the basis of systemic psychological description of consciousness, and ecological consciousness as one of its forms or levels of development:

- composition and the structure of consciousness;

- matter of consciousness

- functions of consciousness

- properties of consciousness;

- ontology of consciousness;

- praxiology of consciousness, as its link with human activity and behaviour;

There are several definitions of ecological consciousness offered by sociology, cultural studies, and philosophy, as well as psychological definitions. These psychological definitions have been analysed in a number of instances in the work of V.I. Panov (2004).

The most popular definition, according to the frequency of its adoption and citation in Russian publications, is as follows (Deryabo, and Yasvin, 1996; Panov, 2004): ecological consciousness (individual and group) is a complex whole of ecological concepts, existing attitudes towards nature, and corresponding strategies and technologies of interaction with it. This is the basic definition currently employed in the majority of psychological and pedagogical studies in Russia. In our view, such a definition, in fact, covers only one dimension of ecological consciousness-the attitude toward nature (the natural world)-and can be considered only as one of the forms of the pluriform ecological consciousness (EC). EC includes other types of relationships, and reality attests to the fact that all the dimensions EC intersect with economic, political, legal, and professional consciousness.

In a second prevalent definition, EC is understood as a system of relationships of a man with the outside world, the possibilities and consequences of changes in these relationships in the interests of the human being and humanity, as well as the distribution of existing concepts and representations of natural phenomena and their mutual links with the human being as a conceptual apparatus (Medvedev, and Aldasheva, 2001). The authors note that the definition of EC suggested by them is close to the definition of that aspect of consciousness known as "worldview."

The principal element of the definition of EC, in our opinion (an idea we share with Kalmykov, 1999), should be the etymology of the notion "ecology": "household," "place of habitation". From this perspective, EC is a multidimensional, dynamic, reflexive plane of human consciousness, incorporating multiple, holistic aspects of interaction of the human being, as a representative of the species and of human society, with the environment and the world (the home, the habitation of the human being). Reflexive consciousness is a form of cognitive abstraction that enables the formulation of values and beliefs, goals and strategies. The relationship of the human being, as a representative of humanity, nature and society, to his or her habitation, touches on relations with the planet, the universe, nature, culture, material objects, and other people. This framework, in our opinion, posits an interrelationship between ecology, as a dimension of the human habitation; and culture, as the existential space of an ethnos, of environmental identity as an integral component of self-consciousness.

In reality, ecological consciousness, understood as a holistic reflexive process of conscious comprehension of the world, and oneself in it, by a human being, is multidimensional. In addition to attitudes toward nature, it includes components of legal, political, professional, and religious consciousness. The necessity of including both the physical world and the world of human beings within the space of EC is made evident by the problem over-consumption, one of the causes of the ecological crisis. The world community has responded by setting the goal of saving the planet and its resources for future generations, which found expression in the concept of sustainable development. Nevertheless, global environmental problems such as climate change, freshwater shortages, 
drought, and natural catastrophes, give rise to ecological conflicts over scarce resources, poverty and illness, migrations, the disappearance of indigenous peoples, and the problem of ecological refugees. All of these issues concern relationships among people.

Thus, the space of existence of ecological consciousness can be represented as the centre of intersecting sets (similar to Venn diagrams): the natural world, the human world, and the world of other material objects. Analysis of a large number of studies on the problems of EC and its individual components showed that $\mathrm{EC}$ is a form of consciousness, and its actual existence does not contradict the principles of multiplicity and polyphony of conscience (borrowing Bakhtin's notion).

The principles of systemic psychological description may be applied to EC in the same way they are applied to consciousness in general. These principles will be presented here in part.

The content of consciousness includes: knowledge of the world and selective knowledge of the components of the external world; attitude toward the world and its components; consciousness of the "self" (selfconsciousness); meaning and semantic content.

In addition, the category of content includes belonging of consciousness to the individual or collective subject. As noted by V.F. Petrenko and O.V. Mitina, both individual and collective subjects, whether persons, groups (e.g. political parties), or society as a whole, have a certain worldview, allowing it to comprehend the world, oneself in it, and to plan and take actions in order to bring about certain effects.

V.F. Petrenko (2005) notes that the notion of "worldview" is close to the notions of "social consciousness" or "societal mentality", used in philosophical literature; but in the context of psychology, the notion of "worldview" comprises both conscious and unconscious planes of cognition. The worldview is thus seen as a complex, multilayered formation that contains religious experience, virtual structures of the arts, ideology, and deep layers of mythological and collective unconscious (Jung's archetypes), in addition to scientific and conceptual knowledge. A psychosomatic approach to the study of the worldview in psychology is realised through the paradigm of constructivism, where the worldview is interpreted not as a mirror reflection of reality, but as one of the possible models of the world created by the individual or collective subject.

Traditionally, the most commonly researched element of EC content is attitude or relationship, which, following the principles of V.N. Mja- sisshev's concept (1995), is seen from the point of view of cognitive, affective, and conative components, as well as such forms of attitude or relationship as goals, views, beliefs, opinions etc.

Among EC attitudes, the following should be singled out: attitude toward or relationship with nature; and attitude toward or relationship with global environmental problems-climate change, biodiversity, forest resources, land resources, freshwater resources, hydrocarbon resources, atmosphere, coastal and marine zones, natural and ecological disasters, food resources, public health and human capital, poverty, urbanization. A third type of attitude toward or relationship with might be the attitude toward social and moral responsibility (secondary reflection) for one's actions and inaction toward nature and the environment. An attitude could be represented as a concern about a problem, understanding of the problem and the role of the anthropogenic factor in causing it, worsening, mitigating, or preventing it; and an inclination for specific behaviour and activity. This is the kind of problem that was called "a social dilemma or the tragedy of the community"-a metaphor proposed by G. Hardin (Hardin, 1968).

The first kind of attitude or relationship is at the intersection of the world of nature and the world of people, and is the core of the EC concept according to Deryabo, Yasvin, Panov, and the majority of Russian researchers. The second and the third types of attitude or relationship are studied more frequently in international psychology, and are prevalent in the interdisciplinary context of global environmental research.

Examining these relationships from the point of view of cognitive, affective and conative components leads us to the following conclusions. Cognitive and affective components are often not the determining factors in the choice of attitudes toward behaviour and activities; knowledge is not always equal to understanding; knowledge does not always define value-motivational attitudes; there is often a contradiction between declared attitudes and real behaviour and activity. Particular care should be taken when interpreting survey results. For example, in the project "The Health of the Planet" of the World Gallup Institute in 1992, Russian respondents answering the question "What do you consider the most important problem for your country?" mentioned environmental problems as important in only $9 \%$ of all cases, occupying almost the last place in a sample of 22 countries, whereas the portion of respondents choosing environmental problems from a predefined list of problems 
was $62 \%$. This illustrates the influence of the social field on the actualisation of a problem occupying the periphery of consciousness.

The affective component of EC attitudes may appear in such phenomena as ecological optimism/ecological pessimism, which in our opinion is conditioned, on the one hand, by inner convictions about the possibility of solving the problem and one's own actions; and, on the other hand, by external attitudes fostered by the mass media. Alarmism, fear, anxiety, and mass panic can be triggered by the media (e.g. popular science publications), as well as suppression of the problem, its distortions or false presentation. Today's global economic crisis is an example of this phenomenon in another area of activity.

On the other hand, as our research shows (Shmeleva, 2006), the evaluation of the significance (the most frightening, the worst) of the global problem from the point of view of the maximum threat for nature and human society is conditioned, first, by past collective experience; and, second, by the level of professional knowledge, i.e. understanding, of the problem. A comparison of data from a Russian sample with the results of international cross-cultural research (Eisler, and Yoshida, 2002) using a similar approach demonstrated that in both Russian and Japanese samples the threat of nuclear weapons was placed highest in rank as a threat to human survival. This may be explained by the Hiroshima and Nagasaki bombings in Japan and the Chernobyl catastrophe in the USSR. It should be noted that the respondents did not live through these experiences personally, nor did they apprehend these experiences in real time, taking into account their ages in 2003-2005.

The conative component of relationship or attitude in Russian EC research is the least studied and the most contradictory. Traditionally, research results demonstrate a gap between the attitude toward active measures or efforts, and the belief that these actions will lead to their goal., As a rule, respondents point to inaction by government and administrative bodies in solving local environmental problems and disbelief in the usefulness of one's own individual contribution and actions.

An important component of EC is self-consciousness as cognitive representation of the self, and the degree to which it includes valued natural objects, the environment, and other people (e.g. members of one's own ethnos).

Evidence of the connection between attitudes toward the environment and attitudes of self-consciousness has led researchers (Schultz,
2001; Schultz et al., 2005) to propose a three-part structure of attitudes, established through experiment in large-scale cross-cultural research. This structure included concern for oneself (ego-attitude); concern for others-one's children, relatives, friends, future generations (altruisticattitude); and concern over the biosphere (biosphere-attitude). According to the researchers, such a structure was a more adequate reflection of today's reality than the dichotomy of the characteristics "anthropospheric/ecospheric". It allows for an active orientation toward the environment on the level of both the individual and the group, relying even on ego-orientation: "what is good for nature, for the biosphere, is good for me." Respondents of five out of six countries demonstrated a higher level of biosphere-orientation than altruistic and egoistic; Russia was the only exception. In characterising the reasons for their concern for nature and the environment, Russian respondents placed themselves at the top (ego-orientation), followed by others (altruistic orientation), and assigned nature (biosphere-orientation) to the last place.

The functioning of EC includes, in addition to functions, such processes as formation and development in ontogenesis, education, and socialization. We would like to point out that the development of EC during late youth and adulthood, during periods of professional development and self-realization, have been studied much less than its development during childhood and teenage years, although it is during the process of professional development and activity that the cognitive function of understanding is activated. As a result of understanding, knowledge becomes part of a person's inner world and influences the regulation of his or her activity (Wecker, 1998; Brudny, 1997).

An overview of the functions of consciousness identified in publications by Russian researchers (Akopov, 2002; Zinchenko, 1991) allows us to single out the following: modification; integration; goal-setting; irradiation; anticipation; creation of an image or a sketch of the future; realisation of the surrounding world and oneself in this world; construction of meanings; reflexivity; generation; meaning-making; regulative, estimative; reflexive; spiritual; function of understanding.

Undoubtedly, EC possesses all the functions inherent in consciousness as a whole. The following functions should be considered as basic, however: the reflexive function, anticipatory function, and spiritual function. The reflexive function has already been characterised above. The significance of the anticipatory function and the need to study it has 
been highlighted in the results of a research project on «The psychology of global changes in the environment" carried out by UNESCO (Pawlik, 1991). Traditionally, the psychological dimension of global change was considered to be dependent on individual or collective ethics, the individual ability to solve conflicts, and the ability of a human being to think and act responsibly at the inter-generational level. The research showed that there are additional psychological problems here, which demand special consideration:

- localisation of signals about global change beyond the threshold of direct perception and memory; the temporal interval between human activity and the environmental impacts beyond the framework of one generation; a temporal gradient that does not allow one to observe and control an effect, and the related psychological problem of delayed gratification;

- psychophysics of low-probability events, leading to subjective underestimation as a function of the low absolute level of their occurrence (e.g. natural catastrophes);

- the problem of social distance between the actors (agents) and the victims of global change.

The axiological component in the development and formation of EC is seen as the most significant for description and study, insofar as the goals and norms, as part of individual and social consciousness, provide benchmarks for the selection of goals and means of action, regulate behaviour of humans and social groups, and define the environmental imperative in internal policy and international cooperation. Modern psychological research considers values as a motivational construct and as an element of consciousness (Rokeach, 1973; Schwartz, and Bilsky, 1987; Schwartz, and Bardi, 2001; Schwartz, 2005; Schleder 1994; Leont'ev, 1998). As the analysis of theoretical insights and empirical research has shown, axiology serves as a key aspect in the study and formation of EC. This aspect has received the least scholarly attention in Russia, for which reason we have chose this as the basic goal of our empirical research.

During the last decade in western psychology, interest in the study of environmental values, applying the methdology of S. Schwarz, has grown considerably, and universalism has been singled out as a highly significant value. Studies demonstrate the interdependence of values, pro-environmental attitudes of consciousness, and pro-environmental behaviour (Schwartz, 2005; Schultz, and Zelezny, 2003; Schultz, 2005; Raudsepp, 2001; Didz, Kalof, and Stern, 2002).

Schwarz's conception of universalism treats it as a motivational goal of the values of transcendency, which include understanding, tolerance, and protection of the well-being of all peoples and nature. This contrasts with the intra-group focus on the values of kindness. Universalist values also derive from the need of individuals and groups to survive. However, these values are not acknowledged until people come into contact with those who are not members of their narrow primary group, and until they become aware of the scarcity of the natural resources they depend on for survival. They may also come to understand that the inability to interact with those who are different from them and to treat them fairly can lead to life-threatening discord, and that failure to protect the environment will lead to the depletion of resources upon which their lives depend. Universalism unites two types of relationship (concern): for the wellbeing of all in a large community and the whole world; and concern for the environment. (Some notions informing this value are: tolerance, broad outlook, social justice, equality, world peace, beauty, unity with nature, wisdom, environmental protection, as well as inner harmony and spiritual life (Schwartz, 2005)).

In our research we posited differences in value orientations of groups with heterogeneous professional orientations; those professionally oriented toward solving ecological problems, problems of sustainable development, and education for sustainable development; and groups of indigenous peoples whose ethnic origins presuppose intimate links and relations with nature and the environment. The results of our study showed that the value of universalism received highest priority among groups of indigenous peoples of the North and professional groups specialising in environmental protection and sustainable development. Universalism as a value was not a priority for students of psychology, pedagogy, and geology, and was rejected by the group of law students. The results obtained (Shmeleva, 2006) suggest the need for a paradigm shift in the field of environmental and sustainable development education, from the transfer of information and creation of knowledge to the formation and development of values and meaning, with the goal of influencing the sphere of motivation and meaning within the individual.

The words of V. Ganzen (1984) on the "multi-facetedness" of modern psychology and the role of systemic analysis and systemic synthesis in or- 
dering the multiplicity of theories and views still hold true. The methodology of systemic psychological description of ecological consciousness might serve as a basis for drawing general conclusions from the disparate theoretical and empirical studies in the field, thus enabling us to understand the psychological implications of the global ecological crisis.

\section{References}

Agafonov, A.Y. (2003). Osnovy smyslovoy teorii soznaniya [The basis of the consciousness theory of meanings]. Sankt-Peterburg: Rech.

Akopov, G.V. (2002). Problema soznaniya v psihologii. Otechestvennaya platforma [The Problem of consciousness in psychology. Domestic Platform]. Samara.

Allackhverdov, V.M. (2003). Soznanie kak paradoks. Eksperimental'naya psihologika, tom 1 [Consciousness as a paradox. Experimental psychologics, vol. 1]. SanktPeterburg.

Anannyev, B.G. (1980). Izbrannye psihologicheskie trudy, tom 1 [A selection of psychological works in two volumes, vol.1]. Moskva.

Backhtin, M.M. (1994). Problemy tvorchestva Dostoevskogo [The problems of Dostoevsky creative work]. Kiev.

Brudny, A.A. (2005). Psihologicheskaya germenevtika [Psychological hermeneutics]. Moskva.

Capra, F. (2002). The Hidden Connections: A Science for Sustainable Living Harper Collins. London.

Deryabo, S.D. (1999). Ekologicheskaya psihologiya: diagnostika ekologicheskogo soznaniya [Ecological Psychology: Diagnostics of Ecological Consciousness]. Moskva.

Didz, Sh., Kalof, L., and Stern, P.C. (2002). Gender Values and Environmentalism. Social Science Quarterly, 83, 1. P. 351-364.

Dunlap, R., and Gellop, G. (1992). Zdorov'e planety [Health of the Planet]. SOCIS, 12. P.11-31.

Evteev, S.A., and Perelet, R.A. (eds.) (1989). Nashe obschee buduschee. Doklad MKOSR [Our Common Future: Report of the World Commission on Environment \& Development]. Moskva: Progress.

Gansen, V.A. (1984). Sistemnye opisaniya v psihologii [The system-defined descriptions in psychology]. Leningrad.

Gumilev, L.N. (1990). Etnogenez i biosfera zemli [Ethnogenis andEearth Biosphere]. Leningrad.

Hardin, G. (1994). The Tragedy of the Commons. In Ch. Pierce, D. Van DeVerr (eds.). People, Penguins, and Plastic Trees. Basic Issues in Environmental Ethics. USA Wadsworth Publishing Group. P. 330-339.
Ivanova, T.I. (1999). Ekologicheskie tsennosti v obschestvennom soznanii Ecological values in public consciousness. Voprosy psychoklogii, 3. P. 83-89.

Kalmikov, A.A. (1999). Vvedenie v ekologicheskuyu psihologiyu. Kurs lekciy [Introduction to ecological psychology. Lecture course]. Moskva.

Leont'ev, D.A. (1998). Tsennostnye predstavleniya v individual'nom i gruppovom soznanii: vidy, determinanty i izmeneniya vo vremeni [Values representations in individual and group consciousness: forms, determinants and changes in time]. Psihologicheskoe obozrenie, 1. P. 13-25.

Medvedev, V.I., and Aldasheva A.A. (2001). Ekologicheskoe soznanie [Ecological consciousness]. Moscow.

Mjasisshev, V. N. (1995). Psihologiya otnosheniy. Izbrannye psihologicheskie trudy [Psychology of Relations. Selected psychological works]. Moskva.

Moiseev, N.N. (2000). Sud'ba tsivilizatsii. Put' razuma [The Destiny of civilization: The path of mind]. Moskva.

Panov, V.I. (2004). Ekologicheskaya psihologiya: opyt postroeniya metodologii [Ecological psychology: the experience of methodology construction]. Moskva.

Pawlik, K. (1991). The psychology of global environmental change: some basic data and agenda for cooperative international research. International journal of psychology, 26, 5. P.547-563.

Petrenko, V.F. (2005). Osnovy psihosemantiki [The basics of psycho semantics]. Sankt-Peterburg: Piter.

Petrenko, V.F., and Mitina, O.V. (1997). Psihosemanticheskiy analiz dinamiki obschestvennogo soznaniya [Psycho semantic analysis of the public consciousness dynamics]. Moskva.

Raikov, V.L. (2002). Mozaichnaya teoriya soznaniya [The Mosaic theory of consciousness]. Mir psihologii, 32, 4. P. 265-276.

Rokeach, V. (1973). The Nature of Human Values. New York.

Rubinshtein, S.L. (1997). Izbrannye filosofskie i psihologicheskie trudy. Osnovy ontologii, logiki, psihologii [Selected Philosophical and psychological works]. Moskva.

Schleder, B. (1994). Struktura tsennostnyh orientatsiy. Empiricheskoe issledovanie [The Structure of Value orientations]. Inostrannaya psihologiya, 2, 4. P. 47-56.

Schultz, W.P., et al. (2005). Values and their Relationship to Environmental Concern and Conservation behavior. Journal of Cross-Cultural Psychology, 36, 4. P. 457-475.

Schultz, W.P., and Zelezny, L.(2003). Reframing environmental messages to be congruent with American values. Human ecology review, 10, 2. P. 26

Raudsepp, M.(2001). Values and environmentalism. Trames Journal of Humanities and Social Sciences, 55/50, 3. P. 211-233.

Schwartz, S.H. (2005). Basic Human Values. Their Content and Structure across Countries. In A. Tamayo, J.B. Porto (eds.). Valores e comportamento nas organizacoes [Values and behavior in organizations]. Brazil: Petropolis. Vozes. P. 21-64. 
Shmeleva, I.A. (2006). Psihologiya ekologicheskogo soznaniya [Psychology of Ecological Consciousness]. Sankt-Peterburg.

Suckhodolsky, G.V. (1998). Vvedenie v matematiko-psihologicheskuyu teoriyu deyatel'nosti [Introduction to the math-psychological theory of activity]. Sankt-Peterburg.

Toward a Sustainable World: The Earth Charter in Action (2005). From: http:// earthcharterinaction.org/eci_book.html

Ulibina, E.V. (2001). Psihologiya obydennogo soznaniya [Psychology of everyday consciousness]. Moskva.

UNEP (1999). Global Environment Outlook 2000. London: Earthscan Publ. Ltd.

Vecker, L.M. (1998). Psihika i real'nost': edinaya teoriya psihicheskih protsessov [Psyche and Reality: the unified theory of psychic processes]. Moskva.

Vernadsky, V.V. (2002). Biosfera i Noosfera [Biosphere and Noosphere]. Moskva.

Yasvin, V.A. (2000). Psihologiya otnosheniya k prirode [Psychology of relations to nature]. Moskva.

Zinchenko, V.P. (1991). Miry soznaniya i struktura soznaniya [The worlds of consciousness and the structure of consciousness]. Voprosy psychoklogii, 2. P. 15.

Zinchenko, V.P, and Morgunov, E.B. (1994). Chelovek razvivayuschiysya [The upcoming human]. Moskva. 